Ann. Biol. anim. Bioch. Biophys., 1978, 18 (2 B), 383-389.

\title{
A study of meiotic chromosomes in bulls carrying the $1 / 29$ translocation
}

\author{
by C. P. POPESCU \\ with the technical assistance of Jeanine BOSCHER \\ Laboratoire de cytogénétique, I.N.R.A.-U.N.C.E.I.A. \\ 78350 Jouy-en-josas, France.
}

Summary. The meiotic chromosomes of 3 bulls carrying the $1 / 29$ Robertsonian translocation have been studied. The abnormal chromosome was found in the spermatogonial mitotic divisions of the 3 animals studied. At the diacinesis stage, the trivalent presented several types of association. Chromosome counting of metaphases II showed the presence of 30.2 p. 100 of unbalanced karyotype cells due to excess or lack of chromosomes.

The Robertsonian $1 / 29$ translocation is the most frequent structural chromosomal abnormality actually known in cattle (Bos taurus L.). It was first described by Gustavsson and Rockborn in 1964 in the Swedish Red breed; since then it has been found in 28 cattle breeds on four different continents (Popescu, 1977). The frequency of this abnormality varies from one breed to another, but it may reach a high frequency in some breeds such as the Swedish Red (Gustavsson, 1969). Like most structural abnormalities, the $1 / 29$ translocation has no visible phenotypical effect, but it causes a decline in the fertility of heterozygous females (Gustavsson, 1969, 1975) and males (Dyrendahl, 1971). The reduction of fertility is attributed to the formation of unbalanced gametes from irregular segregation in the meiosis of the heterozygous animals.

We have identified the $1 / 29$ translocation in the heterozygous and the homozygous state in several French breeds (Popescu, 1971, 1975, 1977). We will present here the first results of a study of the meiotic chromosomes of males heterozygous for the 1/29 translocation. This work was carred out to confirm the presence of the abnormality in the germ line and to evaluate the non-disjunction rate by chromosome counting at the metaphase II stage.

\section{Material and methods.}

We used three bulls previously known to be carriers of the $1 / 29$ translocation in the heterozygous state (Popescu, 1975). Using the method of Evans et al. (1964), meiotic preparations were made of the testes taken from the animals after slaughter. The presence of the trivalent and its configuration were determined at diacinesis. Chromosomes were counted twice on the metaphases II having the best dispersion 

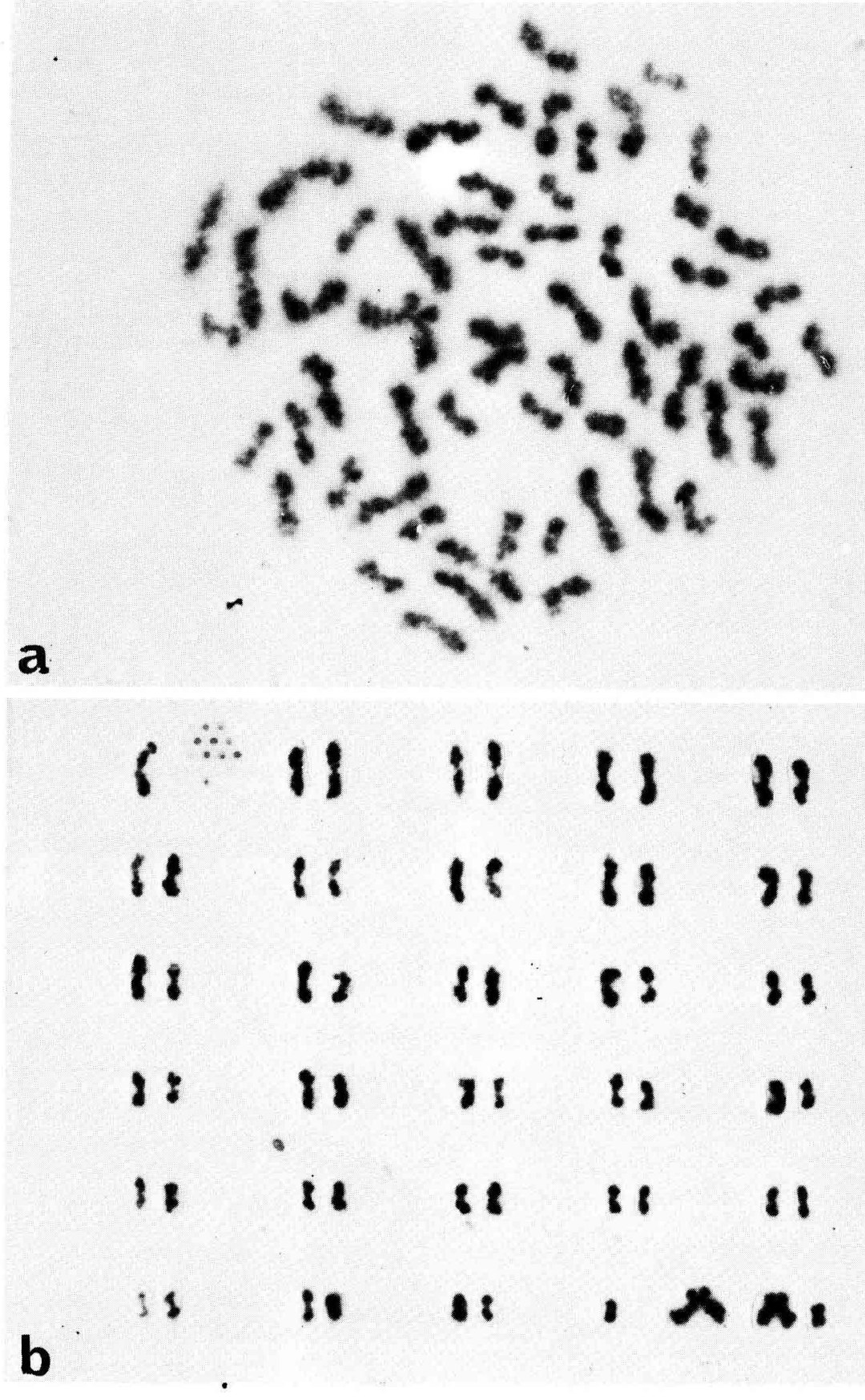

FIG. 1. - Metophase (a) and karyotype (b) of a spermatogonial cell carrying the $1 / 29$ translocation. 


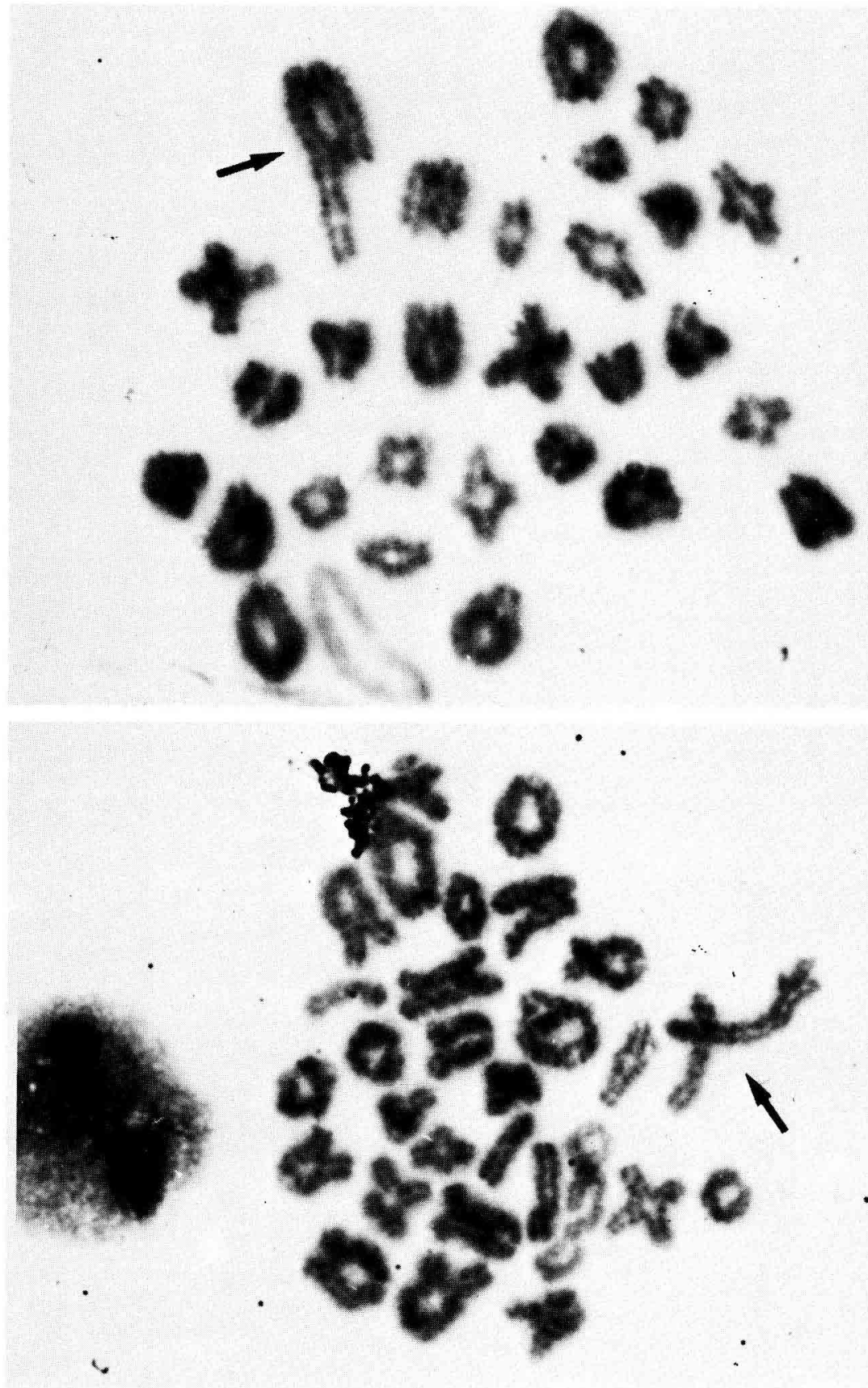

FIG. 2. - Diacineses carrying the $1 / 29$ translecation (arrow indicates the trivalent). 
and photographed at immersion. The disjunction rate was computed using the formula of Ford and Evans (1972) :

$$
\text { Non-disjunction percentage } \frac{\Sigma 29,31 \text { classes }}{\Sigma 29,30,31 \text { classes }} \times 100 \text {. }
$$

\section{Results and discussion.}

The abnormal chromosome was found in spermatogonial mitotic divisions of the 3 males sutdied (fig. 1). At the diacinesis stage, we noticed several types of homologue association in the trivalent (fig. 2), but we could not dtermine a possible irregular segregation by their arrangement. Some diacineses were polyploid, presenting several sex bivalents and as many trivalents. Their artefactual origin in mouse (Ford and Evans, 1971) and cattle (Popescu, 1974) has been previously shown.

Chromosome counting of metaphases II are presented in table 1 . The total number of 109 metaphases studied is low; however, it shows a high percentage of unbalanced karyotype cells (30.2 p. 100). The chromosome number of these cells is affected by an excess (18.8 p. 100, fig. 3), and especially by a lack (81.8 p. 100, fig. 4) of chromosomes. Although the number of cells having less than 29 chromosomes is not very large, it may be supposed that in a certain percentage of cells, unbalanced by lack of chromosomes, loss was random or due to technical treatment. In the case of metaphases II, unbalanced by excess chromosomes, there may be a non-disjunction due to the presence of the trivalent. According to the formula of Ford and Evans applied to our data, the percentage of non-disjunction is $54.6 \mathrm{p}$. 100 . The same formula applied to the data of Gustavsson (1969) and of Logue (1977) gives the comparable figures of 51.6 p. 100 and 45.1 p. 100 , respectively.

TABLE 1

Observations af second metaphase in male heterozygotes

\begin{tabular}{ccccc}
\hline $\begin{array}{c}\text { Number of } \\
\text { chromosomes }\end{array}$ & $\begin{array}{c}\text { Number of metacentric } \\
\text { chromosomes }\end{array}$ & $\begin{array}{c}\text { Sex chromosomes } \\
\mathrm{Y}\end{array}$ & $\begin{array}{c}\text { Total cells } \\
\text { scored }\end{array}$ \\
\hline 28 & 0 & - & 2 & 2 \\
\hline 29 & 1 & 6 & 10 & 15 \\
\hline 30 & 0 & 5 & 17 & 37 \\
\hline 31 & 1 & 20 & 25 & 39 \\
\hline
\end{tabular}

Ford and Evans (1972) showed that various Robertsonian translocations in mouse could behave differently at meiosis ; this was expressed by variable rates of non-disjuntion. In the case of some Robertsonian translocations in in sheep (Bruere, 1974), the cells carrying an unbalanced karyotype seem to undergo negative selection during spermatogenesis (Chapman and Bruere, 1975 ; Long, 1977). 

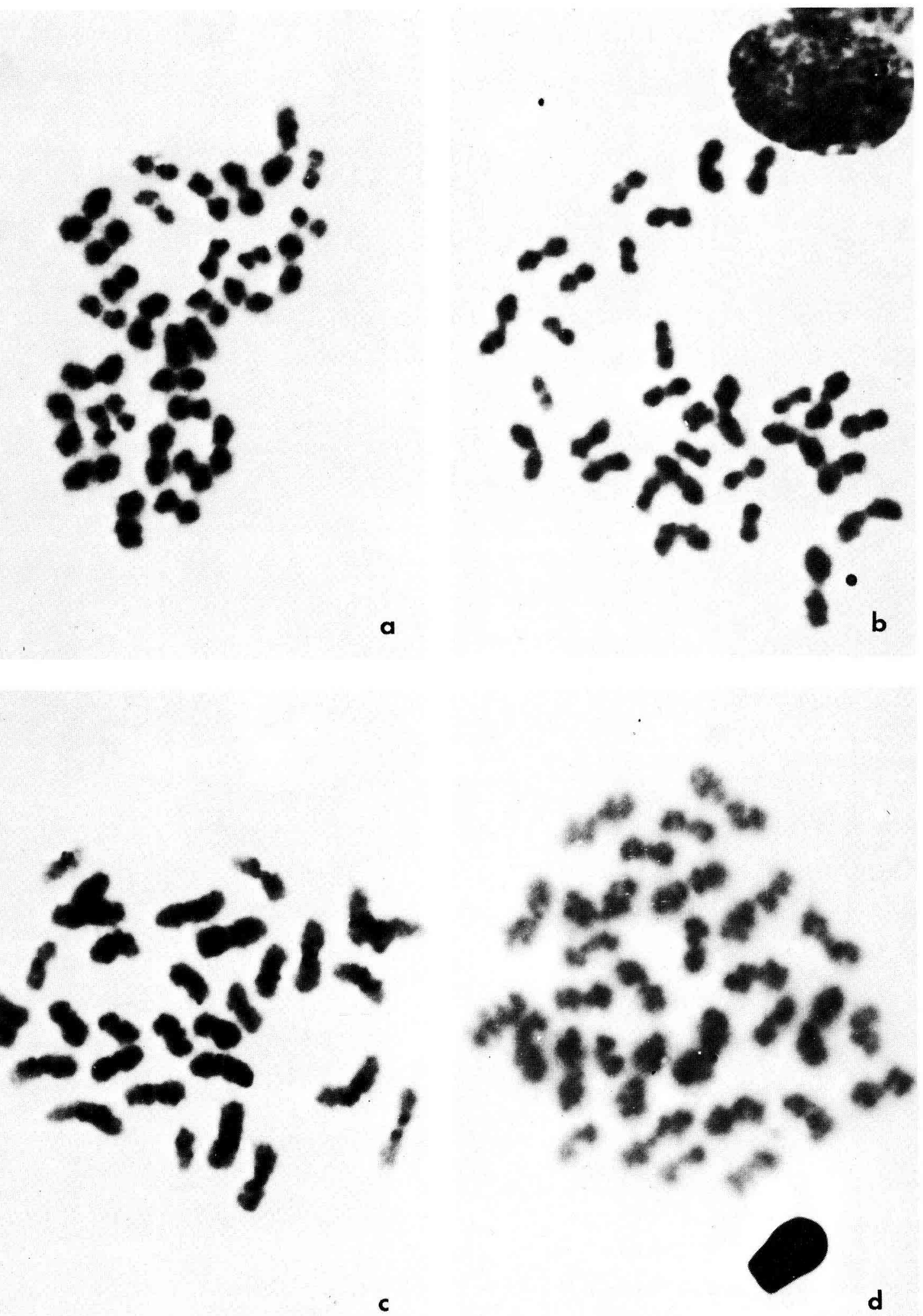

c

FIG. 3. - Metaphases $/ 1$ with a balanced karyotype : a : 30, X; b:30, Y ; $: 29, F, X ; d: 29, F, Y$. 


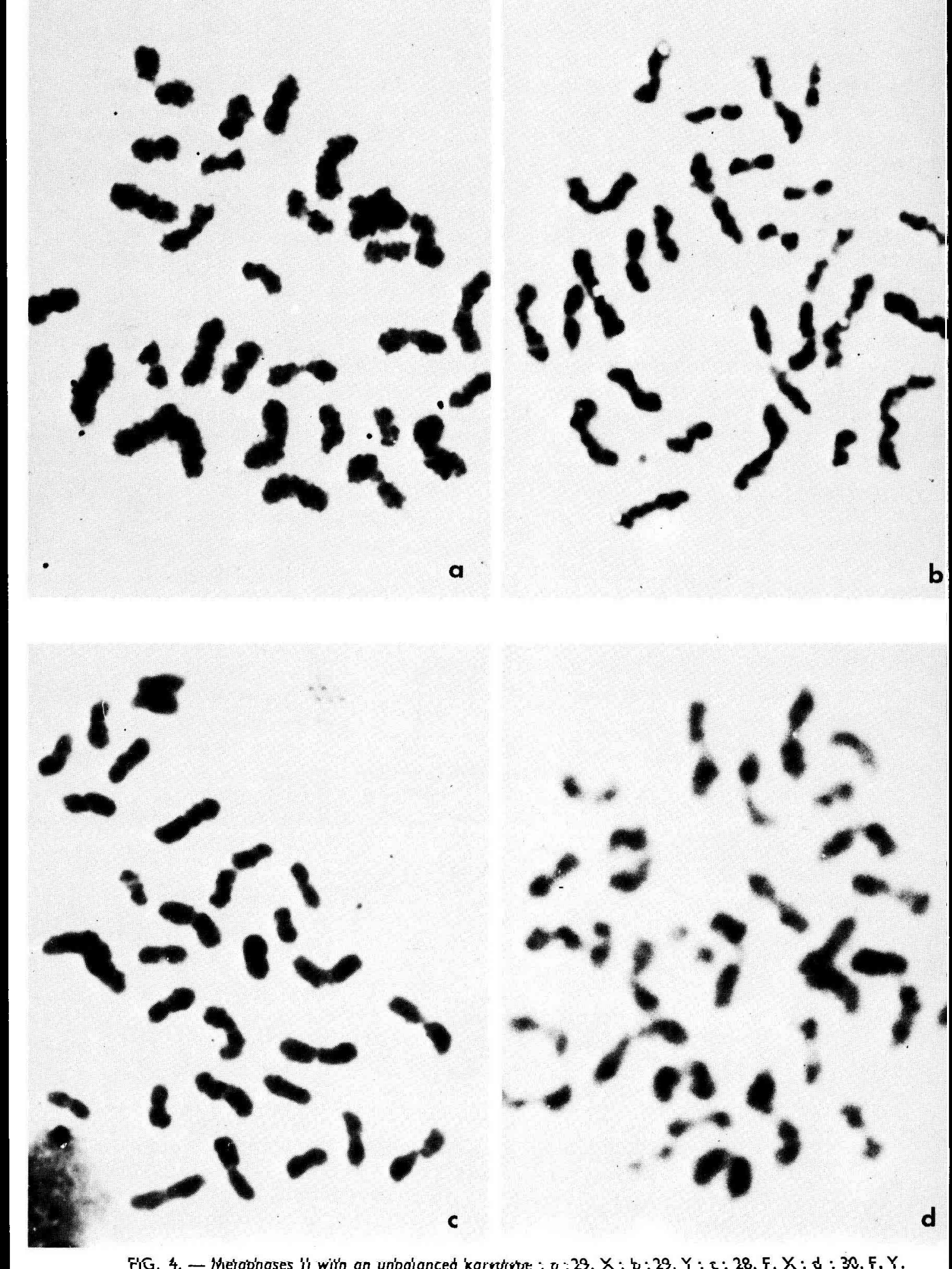


Due to the small sample, our results cannot be considered as conclusive, but they agree with those of Gustavsson (1969) and Logue (1977), confirming the formation of some unbalanced gametes in heterozygotes for the $1 / 29$ translocation.

The mode of trivalent segregation in a heterozygote for a translocation can be studied at the following levels : at meiotic metaphase II stage, in pre-or post-implantation embryos, or in spontaneous abortions. Due to difficulties in obtaining the material in large domestic species such as cattle, only the first level is feasible. The accumulation of data on the meiotic chromosomes of heterozygotes for the 1/29 translocation, as well as on other types of Robertsonian translocation known in cattle, will enable us to better understand their effects on the normal processes of meiosis and on fertility.

$27^{e}$ Congrès international des Sciences physiologiques, Symposium " Germ and somatic cell interaction 》 Paris, 21-23 juillet 1977.

Résumé. Nous avons étudié les chromosomes méiotiques de 3 taureaux porteurs de la translocation Robertsonienne 1/29. Le chromosome anormal était visible au cours des mitoses spermatogoniales chez les 3 animaux étudiés. Au stade diacinèse, le trivalent présentait plusieurs types d'association. Au cours de la métaphase II 30,2 p. 100 des caryotypes ne sont pas équilibrés en raison d'un excès ou d'une perte de chromosomes.

\section{References}

BRUERE A. N., 1974. The segregation patterns and fertility of sheep heterozygous and homozygous for three different Robertsonian transiocation. J. Reprod. Ferf., 41, 453-464.

CHAPMAN H. M., BRUERE A. N., 1975. The frequency of aneuploidy in the secondary spermatocytes of normal and Robertsonian translocation-carrying rams. J. Reprod. Fert. 45, 333-342.

DYRENDAHL I., 1974. Fertiliteten hostjurar med kromosomrubbning. Husd. jur. 5, 20.

EVANS E. P., BRECKON G., FORD C. E., 1964. An air-drying method for meiotic preparations from mammalian testes. Cytogenetics (Basel) 3, 289-294.

FORD C. E., EVANS E. P., 1971. Origin of apparent polyploid spermatocytes in the mouse. Nature, 230, 389-390.

FORD C. E., EVANS E. P., 1972. Robertsonian translocations in mice : segreational irregularities in male heterozygotes and zygotic unbalance. In WAHRAM J., LEWIS K. R., Chromosome Today, 4, 387-397. Proc. Jerusalem chromosome Conf., sept. 11-15.

GUSTAVSSON I., ROCKBORN G., 1964. Chromosome abnormality in three cases of lymphatic leukaemia in cattle. Nature, 203, 990.

GUSTAVSSON I., 1969. Cytogenetics, distribution and phenotypic effects of a translocation in swedish cattle. Hereditas, 63, 68-169.

GUSTAVSSON I., 1975. New information on the reducet fertility of cattle with the $1 / 29$ translocation. 2nd eur. Coll. Cyfogenetics in domestic animals, Giessen, 184-188.

LOGUE D. N., 1977. Meiosis in the domestic ruminants with particular reference to Robertsonian translocations. 3nd eur. Coll. Cytogenetics in domestic onimals, Jouy-en-Josas (in press).

LONG S. E., 1977. Cytogenetic examination of preimplantation blastocysts of ewes mated to rams heterozygous for the Massey I $\left(t_{1}\right)$ translocation. Cytogenet. Cell Genet., 18, 82-89.

POPESCU C. P., 1971. Deux cas nouveaux de fusion centrique chez les bovins. Ann. Génét. Sél. anim., 3, $521-526$.

POPESCU C. P., 1975. Sur la fréquence de la translocation $1 / 29$ dans certaines races bovines. 2 nd eur. Coll. Cyfogenetics in domestic animals, Giessen, 277-282.

POPESCU C. P., 1974. Observations sur les spermatocytes primaires des taureaux (Bos taurus L.) hétérozygotes pour une fusion centrique, 189-194. In BOUÉ A., THIBAULT C., Les accidents chromosomiques de la reproduction. INSERM, Paris.

POPESCU C. P., 1977. Les anomalies chromosomiques des bovins (Bos taurus L.) : état actuel. 3nd eur. Coll. Cyiogenetics in domestic animals, Jouy-en-Josas (in press). 